\title{
Prezentační portál Voda v krajině jako zdroj informací o prírodě blízkých protipovodňových opatřeních
}

\section{VIKTOR LEVITUS}

Klíčová slova: přírodě blízká protipovodňová opatření - mapový portál - mapová kompozice - GIS

\section{SOUHRN}

Článek představuje prezentační portál Voda v krajině (www.vodavkrajine.cz) jako zdroj informací o prírodě blízkých protipovodňových opatřeních. Popisuje obsah a účel jednotlivých částí současné podoby portálu včetně technického řešení a současně zmiňuje úlohu portálu v budoucnosti.

\section{ÚVOD}

Současným účelem prezentačního portálu Voda v krajině (www.vodavkrajine.cz) je přehledná publikace informací a výstupů projektu Strategie ochrany před negativními dopady povodní a erozními jevy prírodě blízkými opatřeními v České republice (dále jen "Strategie"), který řešil Výzkumný ústav vodohospodářský T. G. Masaryka, v. v. i. (dále jen VúV), v období 01/2011-10/2015 ve spolupráci se sdružením dodavatelů Sweco Hydroprojekt a. s., VRV, a. S., WASTECH, a. s., a SINDLAR Group, s. r. o. Projekt se zabýval analýzou současného stavu krajiny

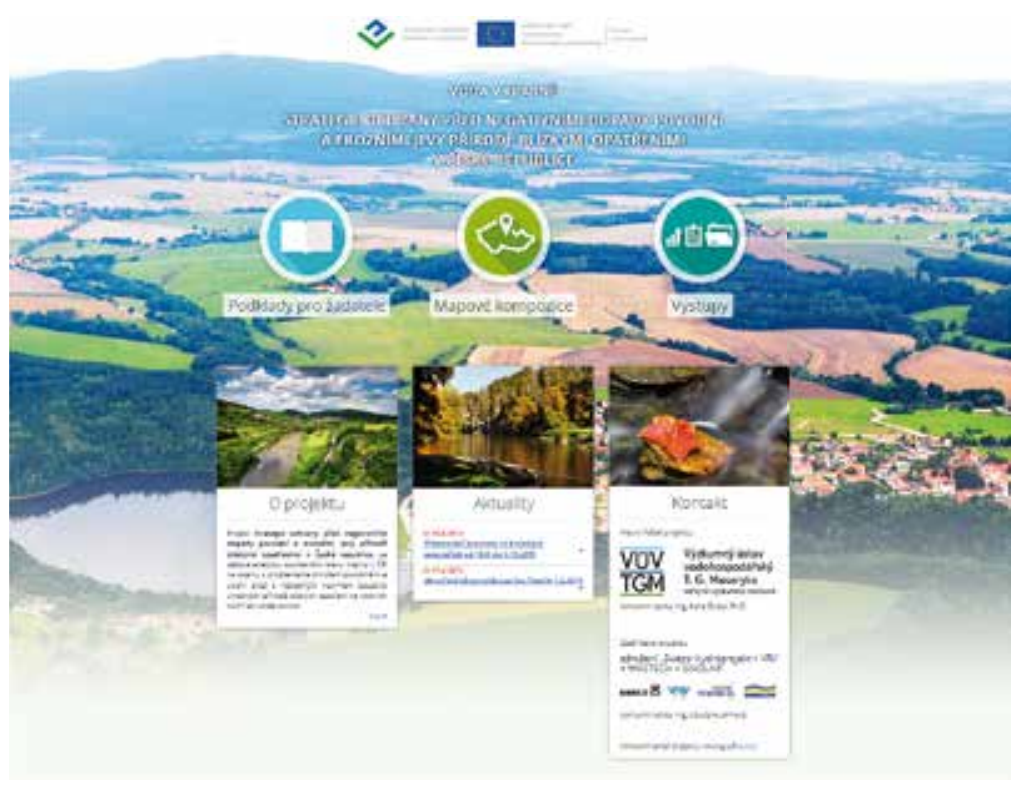

Obr. 1. Úvodní stránka portálu Voda v krajině

Fig. 1. Homepage of the website "Water in the landscape"
České republiky ve vztahu k problematice ohrožení povodněmi a vodní erozí a následným návrhem souborů vhodných prírodě blízkých protipovodňových opatření (dále jen PBPPO) na vodních tocích a v ploše povodí, která pomohou zvýšit míru ochrany ohrožených oblastí. Podoba úvodní stránky portálu je znázorněna na obr. 1.

Na portálu jsou publikovány tyto hlavní informace a materiály:

- popis projektu, aktuality a kontaktní informace;

- popis navržených opatření a jejich prezentace;

- popis mapových kompozic publikovaných formou webových mapových aplikací obsahujících geografická data navržených prírodě blízkých opatření;

- podklady pro žadatele o dotace na realizaci opatření;

- doplňující informace, dokumenty a data ke stažení.

\section{INFORMACE O NAVRŽENÝCH PBPO}

Informace o PBPO navržených v rámci projektu Strategie jsou na portálu publikovány ve formě mapových kompozic a dokumentace.

\section{Mapové kompozice}

Geografická podoba PBPO je prezentována formou několika mapových kompozic, jejichž seznam je dostupný po kliknutí na odkaz "Mapové kompozice" na úvodní stránce portálu, nebo zadáním přímého odkazu www.vodavkrajine.cz/ mapove-kompozice do adresního řádku webového prohližeče.

\section{Jedná se o tyto mapové kompozice:}

— návrhy opatření v povodí kritických bodů,

- návrhy opatření na vodních tocích a nivách,

- návrhy opatření na zemědělské pưdě,

— návrhy systému opatření,

— erozní ohrožení zemědělské půdy,

- hydromorfologie,

- odtokové poměry,

- charakteristiky PUPFL.

Informace o každé mapové kompozici se zobrazí po kliknutí na její název. Náhled informací ukazuje obr.2. 


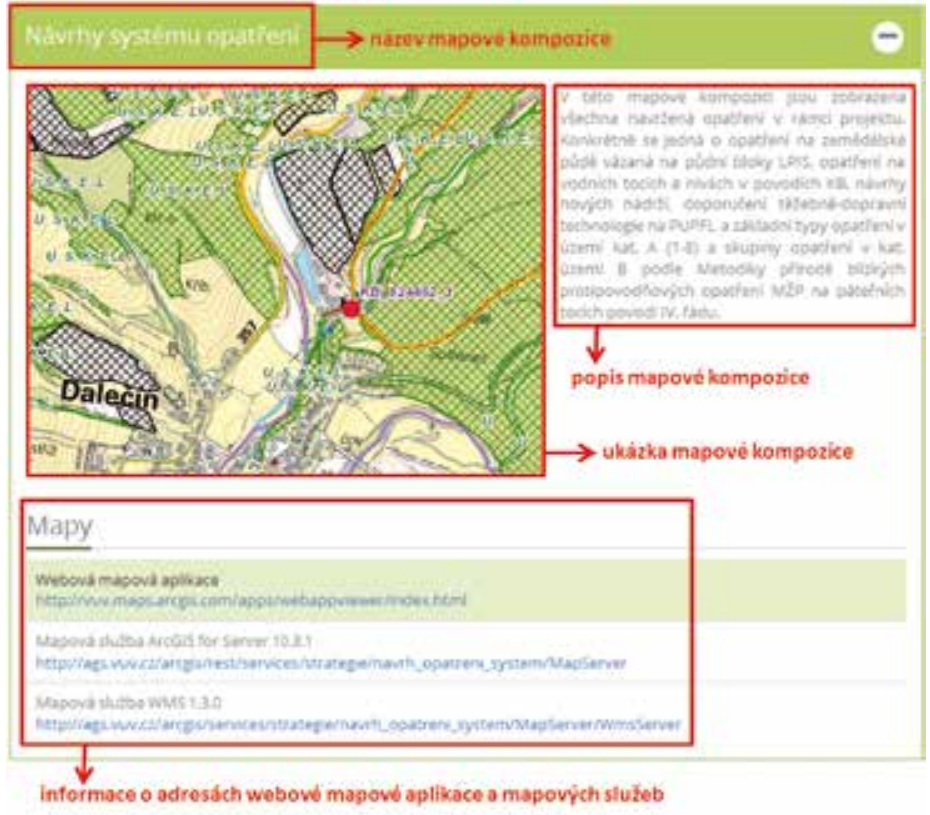

Obr. 2. Informace o mapové kompozici

Fig. 2. Information about map composition

Samotná mapová kompozice je publikována v podobě webové mapové aplikace, která je dostupná po kliknutí na adresu uvedenou v části „Webová mapová aplikace", nebo po kliknutí na obrázek ukázky mapové kompozice.

Uživatelské rozhraní webové mapové aplikace je znázorněno na obr. 3. Podrobný návod k webové mapové aplikaci je možné stáhnout v dolní části úvodní stránky portálu v sekci „Ke stažení" nebo na stránce „Výstupy“ (www.vodavkrajine.cz/vystupy).

Mapovou kompozici je současně možné připojit do vhodného GIS softwaru (ArcGIS Desktop apod.) v podobě mapové služby ArcGIS Server nebo mapové služby WMS. URL adresy pro připojení těchto služeb jsou uvedeny $v$ popisu každé mapové kompozice.

\section{Dokumentace navržených PBPO}

Dokumentace navržených PBPO ve formátu pdf je dostupná po kliknutí na odkaz "Výstupy" na úvodní stránce portálu nebo zadáním přímého odkazu www.vodavkrajine.cz/vystupy do adresního rádku webového prohlížeče. Vybrané části dokumentace je současně možné stáhnout v dolní části úvodní stránky portálu v sekci „Ke stažení”.

\section{Interpretace obsahu mapového portálu}

Výsledná soustava opatření, která je publikována na portálu, představuje návrh cílového stavu území, který vycházel z hodnocení morfologie terénu a odstranění významných kolizí s aktivitami v zastavěném území a prvky VH infrastruktury $\vee$ krajině. Při sestavování této soustavy opatření byla hledána vhodná kombinace PBPO a ostatních opatření. Nejedná se o konečný neměnný stav navržených opatření, ale o podklad, který bude využiván při zpracování podrobných projektových dokumentací jednotlivých prvků protipovodňové a protierozní ochrany v konkrétním území menšího rozsahu.

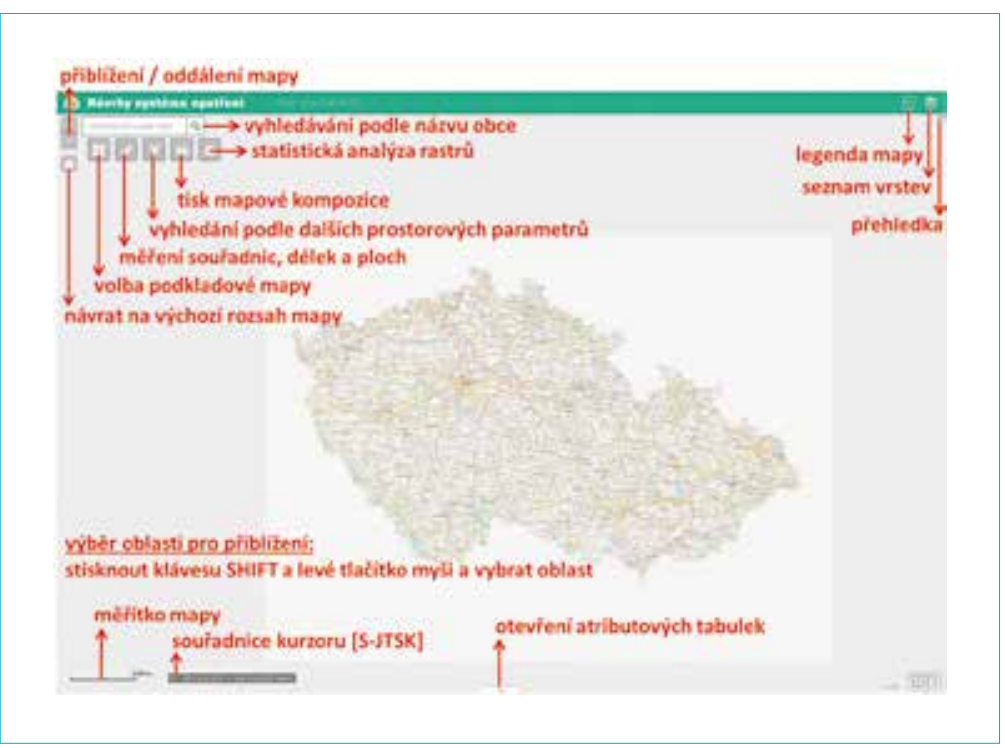

Obr. 3. Uživatelské rozhraní webové mapové aplikace Fig. 3. A user interface of web mapping application

\section{DATOVÝ BALÍČEK}

Portál slouží k prezentaci výstupů popisovaného projektu a umožňuje on-line práci s daty pomocí WMS služeb. Pro potřeby odborné veřejnosti byla také připravena sada datových výstupů, kterou je možné získat na základě žádosti na Odboru ochrany vod Ministerstva životního prostředí. Jedná se především o geografická data ve formátu ESRI shapefile (.shp), která umožňuji jejich prímé využití v prostředí GIS. Obsahem datové sady jsou výsledky vstupních analýz, které byly provedeny v rámci projektu. Jedná se o tato témata:

- Vymezení kategorií území pro různé úrovně podrobnosti zpracování,

- Prostorové informace o využití zemědělského půdního fondu,

- Vymezení hydrologických skupin půd,

- Vymezení drah soustředného odtoku,

- Analýza odtokových poměrů v povodí,

- Lokalizace území ohrožených povodněmi z přivalových srážek (tzv. kritické body),

- Hydrologická bilance,

- Vyhodnocení antropogenního ovlivnění toků,

- Stanovení hydrického režimu lesních půd,

- Stanovení odolnosti lesní půdy vůči těžebně dopravní erozi.

Součástí poskytované datové sady je i výsledná soustava navrhovaných opatrení v ploše povodí, v přispívajících plochách kritických bodů, na tocích a nivách a v podobě malých retenčních nádrží.

Postupy, na jejichžzákladě výše uvedená data vznikla, jsou uvedeny v doprovodných textech, kde je také podrobně popsána struktura vlastních dat.

\section{PODKLADY}

Informace o podkladech pro různá témata týkající se problematiky PBPO jsou dostupné po kliknutí na odkaz „Podklady“ na úvodní stránce portálu, nebo zadáním prímého odkazu www.vodavkrajine.cz/podklady do adresního rádku webového prohlížeče. 
Jedná se tyto typy podkladů:

— informace o dotacích na realizaci PBPO,

- materiály Operačního programu Životní prostředí,

- príručky pro uživatele,

- metodiky a normy,

- publikace,

- ostatní podklady.

\section{ÚLOHA PORTÁLU V BUDOUCNOSTI}

V príštích letech bude hlavní úlohou portálu www.vodavkrajine.cz prezentace informací o PBPO. K současným mapovým kompozicím navržených PBPO budou přidána data PBPO realizovaných za finanční podpory Operačního programu Životní prostředí v letech 2007-2013. Dále budou Odborem ochrany vod Ministerstva životního prostředí průběžně doplňovány informace do sekce "Poklady" s cílem informovat o aktuálních tématech týkajících se problematiky PBPO.

\section{TECHNICKÉ ŘEŠENÍ PORTÁLU}

Portál je tvořen těmito hlavními komponentami:

- webový server,

- systém pro správu dat (redakční systém),

- mapový server

- ArcGIS Online.

\section{Webový server}

Pro technické řešení webového serveru byla zvolena osvědčená kombinace těchto webových technologií:

- webový server Apache,

— databázový server MySQL,

- skriptovací jazyk PHP.

\section{Systém pro správu obsahu (redakční systém)}

Prezentační portál byl postaven na platformě systému Drupal. Jedná se o open source redakční systém pro správu obsahu, který je modulární a umožňuje tvorbu dynamicky orientovaných internetových stránek (internetových časopisů, blogů, internetových obchodů a jiných komplexních systémů). Tato platforma je naprogramována v jazyce PHP, přičemž pro uložení dat může využívat několik typů relačních databázových systémů - v případě popisovaného portálu byla použita relační databáze MySQL.

\section{Mapový server}

Jako mapový server byla použita serverová GIS platforma ArcGIS for Server 10.3.1 společnosti ESRI, která umožňuje publikaci GIS zdrojů v prostředí internetu a jejich využití různými typy klientských aplikací. Hlavní výhodou takového řešení je přenesení většiny požadovaného výpočetního výkonu na stranu serveru, přičemž klientské aplikace mohou být spuštěny na méně výkonných zařizeních různých typů (notebooky, tablety, mobilní telefony apod.).

Prostřednictvím uvedeného mapového serveru jsou mapové kompozice publikovány formou mapových služeb ArcGIS for Server a WMS, přičemž mapové služby ArcGIS for Server tvoří obsah webových mapových aplikací.

\section{ArcGIS Online}

Pro účely publikace mapových kompozic webovými mapovými aplikacemi byla zvolena platforma ArcGIS Online (https://www.arcgis.com/home/), která $\checkmark$ kombinaci se službami publikovanými technologií ArcGIS for Server umožňuje komfortní tvorbu výkonných webových mapových aplikací. Pro každou mapovou kompozici byla vytvořena samostatná webová aplikace. URL adresy jednotlivých webových mapových aplikací jsou uvedeny v části "Mapové kompozice".

\section{ZÁVĚR}

Portál Voda $\vee$ krajině (www.vodavkrajine.cz) je platformou pro prezentaci informací týkajících se problematiky PBPO. Na portálu jsou přehlednou formou publikovány informace o navržených PBPO, a to jak $v$ podobě mapových kompozic (webové mapové aplikace - viz www.vodavkrajine.cz/mapove-kompozice), tak formou doplňující dokumentace (viz www.vodavkrajine.cz/ vystupy). V budoucnu budou na portálu publikována data PBPO realizovaných za finanční podpory Operačního programu Životní prostředí v letech 2007-2013 a sekce Podklady, která obsahuje informace pro různá témata týkající se problematiky PBPO, bude Odborem ochrany vod Ministerstva životního prostředí průběžně doplňována aktuálními informacemi.

\section{Autor}

Ing. Viktor Levitus

凶viktor_levitus@vuv.cz

Výzkumný ústav vodohospodářský T. G. Masaryka, v. v. i.

Př́spěvek prošel lektorským ř́zením.

\section{PRESENTATION PORTAL "VODA V KRAJINĚ" AS A SOURCE OF INFORMATION ON NATURAL WATER RETENTION MEASURES}

\section{LEVITUS, V.}

TGM Water Research Institute, p. r. i.

Keywords: natural water retention measures map portal - map composition - GIS

Article introduces presentation portal "Voda v krajině" (www.vodavkrajine.cz) as an information source about natural water retention measures. It describes content and purpose of induvidual parts of the current form of the portal including technical solution and it mentions the role of the portal in the future. 